\title{
Optimization of a new Ni-free Ti alloy for applications in the implant field
}

\author{
M. GONZÁLEZ ${ }^{1,2}$, M. ARCINIEGAS ${ }^{1}$, F.J. GIL ${ }^{1}$, J. PEÑA' ${ }^{1,2}$, J.M. MANERO ${ }^{1}$. \\ ${ }^{1}$ Departament of Materials Science and Metallurgy, Universitat Politècnica de Catalunya. \\ ${ }^{2}$ Materials science, Elisava Escola Superior de Disseny.
}

\begin{abstract}
Three new Ni-free Ti alloys, Ti-16.2Hf-24.8Nb-1Zr, Ti-5.2Hf-31.2Nb-0.4Zr and Ti-16Hf-36.2Nb$1 Z r(w t \%)$, were designed and produced in order to obtain shape memory and/or low elastic modulus materials in order to avoid stress shielding and to enhance bone regeneration in the load transfer implant field. The alloys were microstructurally and mechanically characterized, cytotoxicity was evaluated using MG63 osteoblast-like cells. The elastic modulus of the new alloys (between 67-90 GPa) are smaller than those of the commercial alloys employed for implantation. The lowest elastic modulus alloy, Ti-16.2Hf-24.8Nb-1Zr (wt \%), with $67.5 \mathrm{GPa}$, was optimized by cold work in order to determine the key factor that promotes the desired shape memory properties and/or low elastic modulus.

A higher proportion of martensite was observed by optical and electron transmission microscopy in the low cold work samples compared to the quenched alloy. The elastic modulus for each cold work condition was evaluated by nanoindentation tests using a spherical tip. The elastic modulus decreases when increasing the cold work level. The lowest value corresponds to the $99 \%$ cold work condition, with $44 \mathrm{GPa}$, closer to that of cortical bone and smaller than the quenched alloy $(67.5 \mathrm{GPa})$.
\end{abstract}

Keywords: Nanoindentation, shape memory effect, low elastic modulus, Ni-free Ti alloys.

\section{Resumen}

Tres nuevas aleaciones de Ti libres de Ni, Ti-16.2Hf-24.8Nb-1Zr, Ti-5.2Hf-31.2Nb-0.4Zr y Ti$16 \mathrm{Hf}-36.2 \mathrm{Nb}-1 \mathrm{Zr}$, porcentajes en peso, fueron diseñadas y fabricadas con el fin de obtener memoria de forma y/o bajo módulo elástico con el objetivo de evitar el apantallamiento de cargas y mejorar la regeneración ósea en el campo de la implantología de transferencia de carga. Las aleaciones fueron caracterizadas microestructural y mecánicamente y la citotoxicidad fue evaluada utilizando osteoblastos MG63. El módulo elástico de las nuevas aleaciones (entre 67-90 GPa) es menor que el de las aleaciones comerciales utilizadas en implantología. El menor módulo elástico corresponde a la aleación Ti-16.2Hf-24.8Nb-1Zr, con 67.5 GPa y fue optimizado mediante trabajo en frío con el objetivo de determinar el factor responsable de la obtención de las propiedades deseadas de bajo módulo elástico y/o memoria de forma.

Una mayor proporción de martensita fue observada por microscopía óptica y microscopía electrónica de transmisión en las muestras con bajo porcentaje de trabajo en frío en comparación con la muestra templada. El módulo elástico correspondiente a cada condición de trabajo en frío fue evaluado mediante nanoindentación con punta esférica. El módulo elástico disminuye al aumentar el porcentaje de trabajo en frío. El menor valor corresponde a la condición de $95 \%$ de trabajo en frío, con $44 \mathrm{GPa}$, valor cercano al del hueso cortical y menor que el del material templado (67.5 GPa).

Palabras clave: Nanoindentación, efecto memoria de forma, bajo módulo elástico, aleaciones de Ti libres de Ni.

Correspondencia:

Marta González

E-mail:marta.gonzalez.colominas@upc.edu

Fax number: 934016706 


\section{Introduction}

In the biomaterials filed, NiTi alloys have been widely used due to their shape memory effect, superelasticity, high damping capacity and corrosion resistance. Their ability to recover a predetermined shape when heated or stressed is due to a reversible solid-state phase transformation from austenite to martensite. Recently, it has been reported that $\mathrm{Ni}$ produces adverse reactions, such as allergy. This fact has stimulated the development of new Nifree Ti shape memory alloys. The most commercial alloys used as implant materials presents elastic modulus of $110 \mathrm{GPa}$ up to $220 \mathrm{GPa}$ from Ti and Co-Cr-Mo alloys, respectively. The research of new alloys is specially focusing on $\beta$-type Ti alloys that exhibit lower elastic modulus and possible martensitic transformation. These properties reduce the shielding effect and enhance bone remodeling [1]. Moreover, $\beta$-Ti alloys offer a high ductility which promotes a good coldworkability which permits the modification of the elastic modulus and mechanical strength through microstructural changes $[2,3]$. The most common $\beta$-stabilizing elements are $\mathrm{Nb}, \mathrm{Ta}$, $\mathrm{Zr}$, Hf and Mo. A good example is the super multifunctional Ti alloy «gum metal», fundamentally expressed as $\mathrm{Ti}_{3}(\mathrm{Ta}+\mathrm{Nb}+\mathrm{V})+(\mathrm{Zr}+\mathrm{Hf})+\mathrm{O}$, which has been investigated by Saito et al. and patented by Toyota inc. in 2003, for automotive applications. This alloy presents a Young's modulus of $44 \mathrm{GPa}$, which was obtained through a dislocation-free plastic deformation mechanism [4].

In order to decrease the time and cost of experimentation, some researchers $[5,6]$ have used a design method to consider the effect of alloying elements for predicting the stable phase of Ti-alloys. The method is based on phase stability maps as functions of two quantum parameters: the bond order (Bo) and the d-orbital energy level (Md). Bo represents the covalent bond strength between $\mathrm{Ti}$ and the alloying element and Md is correlated with the electronegativity and metallic radius of the element.

Due to the affinity for interstitial elements and to the high melting point of the alloying elements, these kinds of alloys must be produced in high temperature vacuum furnaces. The production cost increase limits the quantity of material produced and justifies the election of the nanoindentation, which is an useful technique to evaluate the mechanical properties of small size samples [7]. The Berkovich tips are generally used to determine elastic modulus from the unloading loaddisplacement data, because plastic deformation is achieved at a very low indentation depth. Spherical tips are used to study the elasto-plastic response $[8,9]$ by using the Hertz contact theory.

The aim of the work is to achieve a material with shape memory properties and/or low elastic modulus for use in load transfer implantology. Three new Ni-free Ti alloys were designed and produced using the above-mentioned theoretical method to decrease the time and cost of experimentation. The alloy that presented the best results in terms of low modulus and /or shape memory properties was selected and optimized by cold working. The influence of cold work in the microstructural and mechanical properties was characterized, especially focused on the influence in the elastic modulus.

\section{Experimental}

A theoretical method based on molecular orbitals was used to predict the stable phase and design a new Ti alloy with a significant reduction in terms both of time and cost [10]. Three pairs of $(\overline{B o}, \overline{M d}$ ), were selected on the $\beta$-zone, in the frontier between the low elastic modulus and the shape memory effect. The compositions were determined by using $\mathrm{Nb}$, $\mathrm{Hf}$ and $\mathrm{Zr}$ as alloying elements and the result are the Ti-21.6Hf-23.7Nb$1 \mathrm{Zr}$, Ti-5.2Hf-31.2Nb-0.4Zr and Ti-16Hf-36.2Nb$1 \mathrm{Zr}$ (wt \%) alloys.

A $40 \mathrm{~g}$ button of each alloy was made by arc vacuum melting using high purity (99.99\%) starting elemental materials. The buttons were sealed under vacuum into a quartz capsule, homogenized at $1100^{\circ} \mathrm{C}$ for 12 hours, solution treated at $1100^{\circ} \mathrm{C}$ for 1.5 hours and quenched in ice water. The samples were mechanically polished and finished with colloidal silica to give a surface roughness with a $\mathrm{Ra}<100 \mathrm{~nm}$. The chemical composition was verified by X-Ray Fluorescence in a sample of $180 \mathrm{~mm}^{2}$ of effective area by using a Philips PW2400 equipment at $60 \mathrm{kV}$. A sample of Ti c.p. grade 2 was used as a control.

To evaluate the cytotoxicity, extracts of each alloy were prepared by immersing the samples in cell culture medium (Dulbecco's Modified Eagle Medium, $1 \%$ L-glutamine, $1 \%$ sodium piruvate, $1 \%$ penicillin and $10 \%$ fetal calf serum) for 72 hours at $37^{\circ} \mathrm{C}$. Following the recommendation given in normative UNE-EN ISO 10993-12 a ratio of $3 \mathrm{~cm}^{2}$ $/ 1 \mathrm{ml}$ was used to prepare the extracts. MG63 osteoblast-like cells (ATCC-CRL-1427) were used for the test. 5000 cells/well were sealed in a 96 well plate. Cells were allowed to attach for 24 hours 
and then the extracts were supplemented to the wells. Cytotoxicity was evaluated after 24 hours of cells being in contact with the extracts. Normal cell culture medium was used as negative control and medium with a $2 \%$ of sodium dodecyl sulphate as positive control. Cytotoxicity was evaluated by using cell proliferation reagent WST-1 Roche, based on the measurement of the absorbance of formazan produced by the viable cells. Absorbance was measured in a Power WaveX, Bio-Tek Instruments,Inc. Spectrophotometer using $\lambda=450 \mathrm{~nm}$. The material is considered non-cytotoxic when the ratio between absorbance measured from the negative control and the well plates cultured with extracts is above $75 \%$.

Samples of the alloy number 1 were cold-rolled with a reduction in thickness of $5,10,20,40,90,95$ and $99 \%$ with a maximum of $5 \%$ reduction in each step. One sample for each cold work percentage was microstructural and mechanical characterized. Optical microstructural analysis was carried out using Olympus GX51 microscope after Keller reactive attack $\left(2 \mathrm{~mL} \mathrm{HF}, 3 \mathrm{~mL} \mathrm{HCl}, 5 \mathrm{~mL} \mathrm{HNO}_{3}\right.$ and $190 \mathrm{~mL}$ distilled $\mathrm{H}_{2} \mathrm{O}$ ). X-ray diffraction measurements were carried out at room temperature in an X-ray diffractometer D8 Advance Bruker using $\mathrm{Cu}$ Ká radiation $(\lambda=1.542 \AA)$. Thin disks of $3 \mathrm{~mm}$ diameter were electropolished for transmission electron microscopy (TEM) in an electrolyte consisting of $400 \mathrm{~mL}$ butoxyethanol, $400 \mathrm{~mL}$ methanol and $100 \mathrm{~mL}$ perchloric acid.

Nanoindentation tests were conducted using a MTS Nano Indenter XP with Continuous Stiffness Measurement (CSM) module. Elastic modulus was measured from load-unload tests to depth of $2000 \mathrm{~nm}$ using a Berkovich tip with a measured radius of $750 \mathrm{~nm}$ and using the Oliver \& Pharr method $[8,11]$. In addition, monotonic nanoindentation tests to depth of $100 \mathrm{~nm}$ were developed using a spherical tip of radius

$25 \mu \mathrm{m}$ to determine the reduced elastic modulus in the cold worked alloy by using the Hertz contact theory [12] in the elastic deformation range through the equation 1 . For each test condition 9 indentations were performed for each sample.

$$
F=\frac{4}{3} E^{*} R^{1 / 2} h^{3 / 2}
$$

Where $\mathrm{E}^{*}$ is the reduced elastic modulus, $\mathrm{R}$ is the tip radius and $h$, the indentation depth.

The elastic modulus was calculated from the reduced modulus by using equation 2 . The Poisson coefficient of 0.37 corresponding to the Beta III alloy [13] was used as $v_{\mathrm{m}}$. We have to take into account that a variation of 0.03 in the $v_{\mathrm{m}}$ will modify the $\mathrm{E}_{\mathrm{m}}$ in just $1 \mathrm{GPa}$.

$$
\frac{1}{E^{*}}=\frac{1-v_{m}^{2}}{E_{m}}+\frac{1-v_{i}^{2}}{E_{i}}
$$

Where $\mathrm{E}^{*}$ is the reduced modulus, $\mathrm{E}_{\mathrm{m}}, v_{\mathrm{m}}$ and $\mathrm{E}_{\mathrm{i}}$, $v_{\mathrm{i}}$ and are the elastic modulus and Poisson coefficient of the material, and of the indenter material, diamond, respectively [14].

\section{Results and discussion}

The relevant properties of the microstructural and mechanical characterization of the three new alloys are shown in Table 1. The chemical composition calculated by X-Ray Fluorescence and relative standard deviation for each element are reported in Table 2. As it was expected, due to the high content in $\beta$-stabilizing elements, mainly $\beta$ phase was observed in the new alloys. The elastic modulus of the three alloys was lower than those presented by the commercial alloys used as implant materials.

Figure 1 shows the cytotoxicity results corresponding to alloys numbered as 1, 2 and 3 . The three alloys are non cytotoxic because they show a cell number ratio above the $75 \%$ of the negative control. This means that the ions released by the alloys after 24 hours did not have an adverse effect on the cells.

The alloy numbered as 1 was selected for being optimized by cold roll due to its low elastic modulus, the presence of $\beta$-phase with fine and disorientated $\alpha$ " plates nucleated from grain boundaries and its non cytotoxicity.

A higher proportion of martensitic plates were found by optical microscopy in the samples with 5 to $40 \%$ reduction in thickness, especially in $5 \%$, than in the quenched alloy (figure 2). The martensitic transformation was induced by coldrolling. After $75 \%$ cold work it was difficult to observe the microstructure by optical microscopy due to the nucleation and grow of new grains which formed a nanocrystalline structure, recently reported in metastable Ti alloys with reduction in thickness above $50 \%$ [3]. 


\begin{tabular}{|l|c|c|c|}
\hline Chemical composition (wt \%) & $\mathbf{N}^{\circ}$ & Microstructure & E (GPa) \\
\hline Ti-16.2Hf-24.8Nb-1Zr & 1 & $\beta+\alpha^{\prime \prime}$ & $74 \pm 1.5$ \\
Ti-5.2Hf-31.2Nb-0.4Zr & 2 & $\beta+\alpha$ & $76 \pm 4$ \\
Ti-16Hf-36.2Nb-1Zr & 3 & $\beta$ & $91 \pm 2$ \\
\hline
\end{tabular}

Table 1. Relevant properties of the three new alloys: chemical composition (wt $\%$ ), microstructure and elastic modulus calculated by using a Berkovich tip(GPa).

\begin{tabular}{|c|c|c|c|c|c|c|c|c|}
\hline \multicolumn{3}{|l|}{ Alloy 1} & \multicolumn{3}{|l|}{ Alloy 2} & \multicolumn{3}{|l|}{ Alloy 3} \\
\hline Element & $w t \%$ & St. Dv. & Element & wt $\%$ & St. Dv. & Elemento & wt $\%$ & St. Dv. \\
\hline $\mathrm{Ti}$ & 57.75 & 0.44 & $\mathrm{Ti}$ & 63.10 & 0.43 & $\mathrm{Ti}$ & 46.65 & 0.44 \\
\hline Nb & 24.85 & 0.17 & $\mathbf{N b}$ & 31.22 & 0.18 & Nb & 36.25 & 0.19 \\
\hline Hf & 16.21 & 0.29 & Hf & 5.24 & 0.17 & $\mathrm{Hf}$ & 15.97 & 0.29 \\
\hline $\mathrm{Zr}$ & 1.05 & 0.02 & $\mathrm{Zr}$ & 0.36 & 0.01 & $\mathrm{Zr}$ & 1.06 & 0.02 \\
\hline
\end{tabular}

Table 2. Chemical composition of the three new alloys in $\mathrm{wt} \%$ calculated by X-Ray Fluorescence.

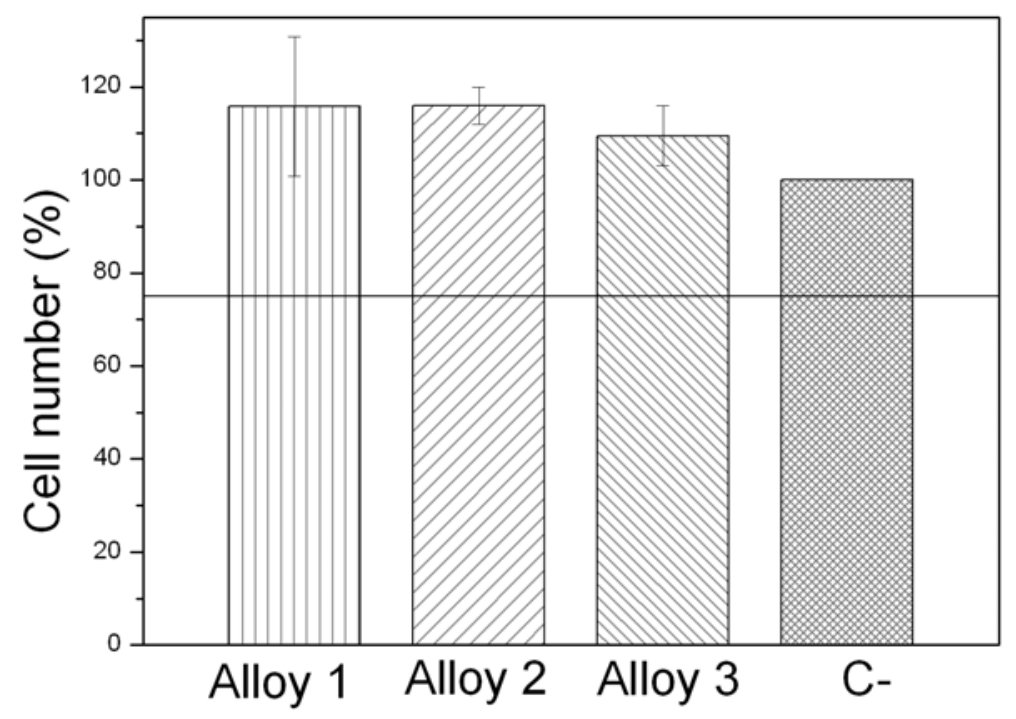

Figure 1. Cell number percentages respect to the negative control of the three studied alloys. 

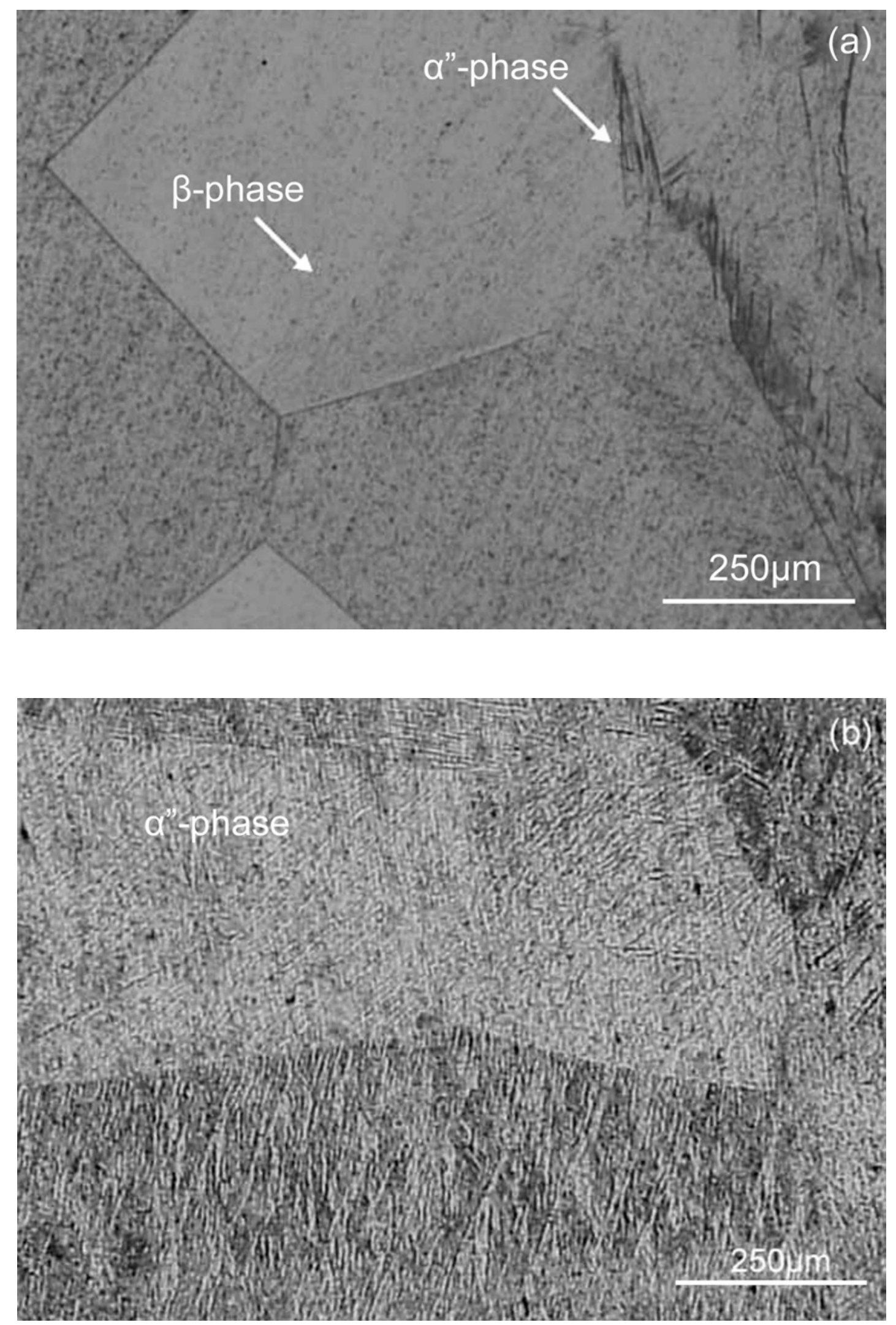

Figure 2. Optical microscopy images of the alloy in the original condition (a) and with $5 \%$ reduction in thickness (b). 
The presence of $\beta$-phase in all the cold work conditions was confirmed by X-ray diffraction analysis (figure 3 ). It is worth to highlight that $\alpha$ "phase was especially present after $5 \%$ cold working. The stress induced martensitic transformation started with 5\% cold work and was stabilized after $10 \%$ cold work.
A bright field image obtained by TEM from the $90 \%$ cold-rolled alloy is shown in picture 4 , where the formation of the nanocrystalline structure with grain size less than $50 \mathrm{~nm}$ can be observed. Inset in figure 4 shows corresponding selected-area electron diffraction pattern with diffraction rings, characteristic of the presence of many crystalline

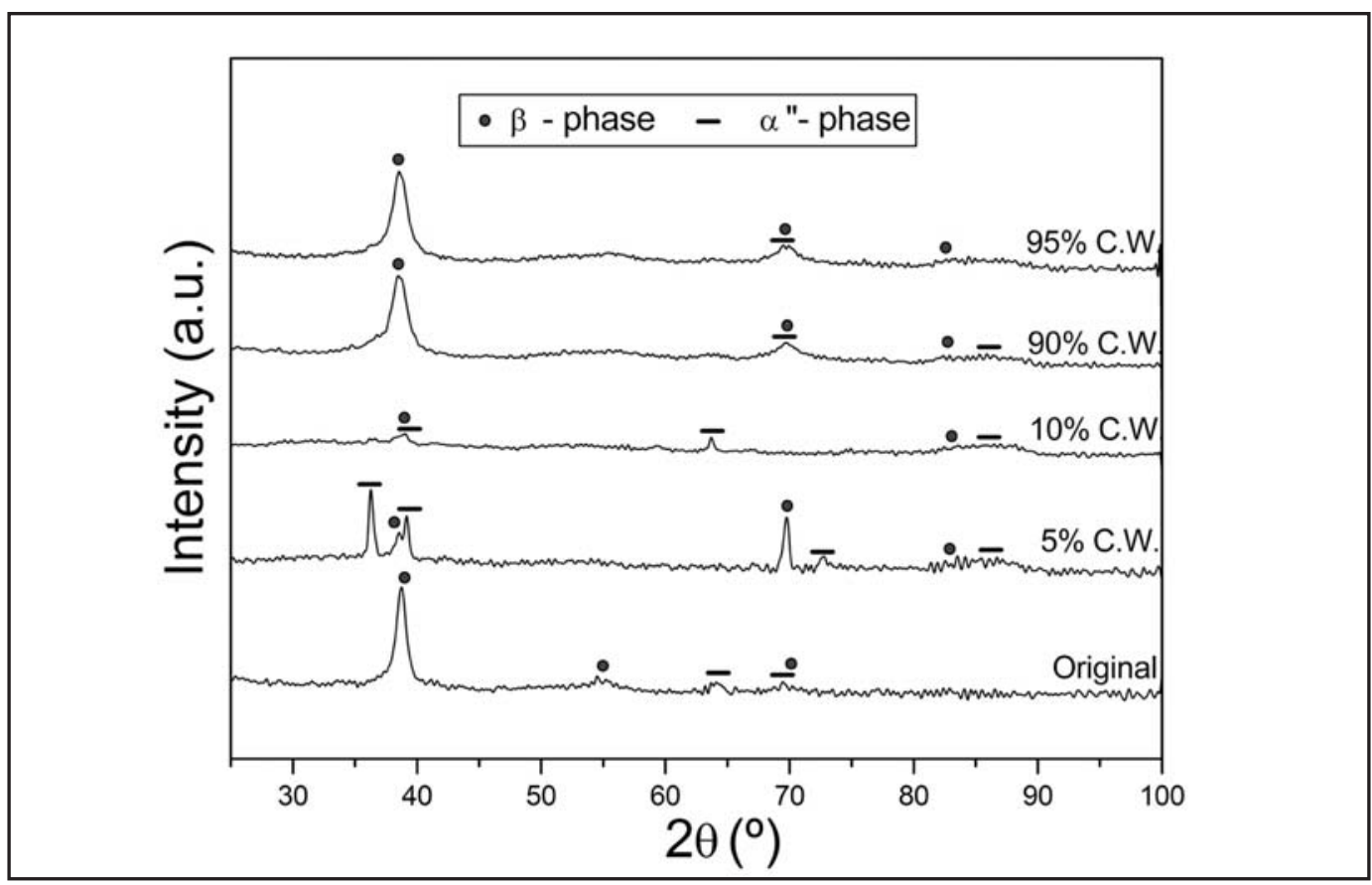

Figure 3. X-Ray Diffraction patterns of the alloy in the original condition and after different coldwork treatments.

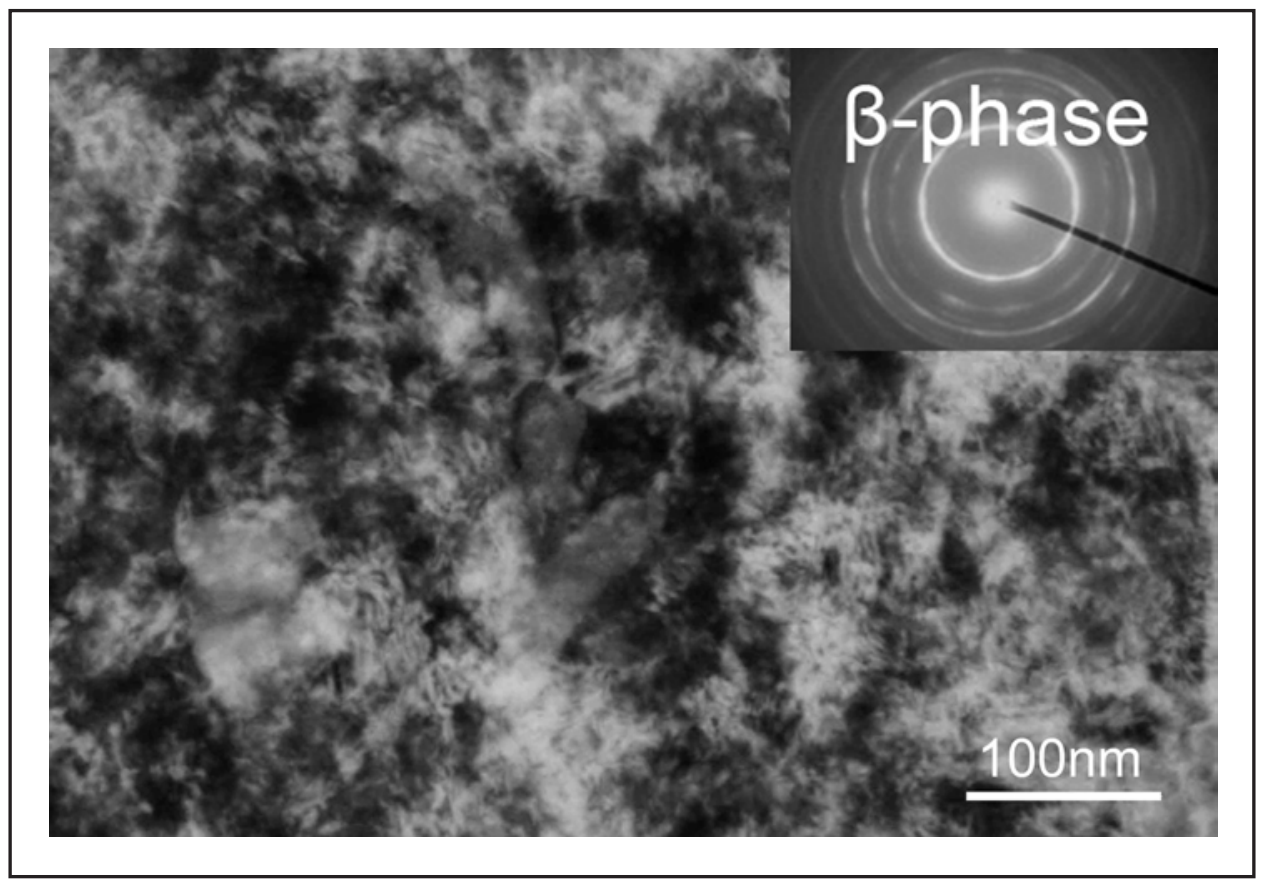

Figure 4. Bright-field TEM image of the $90 \%$ cold rolled alloy and electron diffraction pattern of the selected area. 
grains. The indexation of the pattern corresponds to the reticular parameters of $\beta$ and $\alpha$ "-phases.

The nanoindentation results associated with the spherical tip showed a pronounced decrease in elastic modulus, from 67.5 to $44 \mathrm{GPa}$, corresponding to the quenched alloy and after $99 \%$ reduction in thickness (figure 5). The severe plastic deformation induced by cold-roll refined coarse grains to tens of nanometer. As a consequence of the formation of a nanocrystalline structure the dislocation activity was reduced and grain boundary mediated deformation became dominant. The unusual deformation mechanism originated a lack of hardening mechanisms and the strengthening in accordance with Hall-Petch relation was less significant. As a results, the elastic modulus decreased, caused by the large fraction of atoms which are present in the grain boundaries having a lower elastic modulus $[15,16,17]$.

\section{Conclusions}

The following conclusions can be drawn from this work:

The ions released by the alloys numbered as 1 , 2 and 3 after 24 hours does not have an adverse effect on the cells. However, future studies should be done to evaluate the cell attachment, cell proliferation and cell differentiation and the cell substrate interaction.

The alloy numbered as 1 was selected for being optimized by cold roll due to its low elastic modulus, the presence of $\beta$-phase with fine and disorientated $\alpha "$.

It is worth to highlight the low elastic modulus (44 GPa), which is near to that of cortical bone, exhibited by the $99 \%$ cold worked alloy. This makes it a good candidate for load transfer implants, enhancing bone remodeling due to the reduction of the shielding effect.

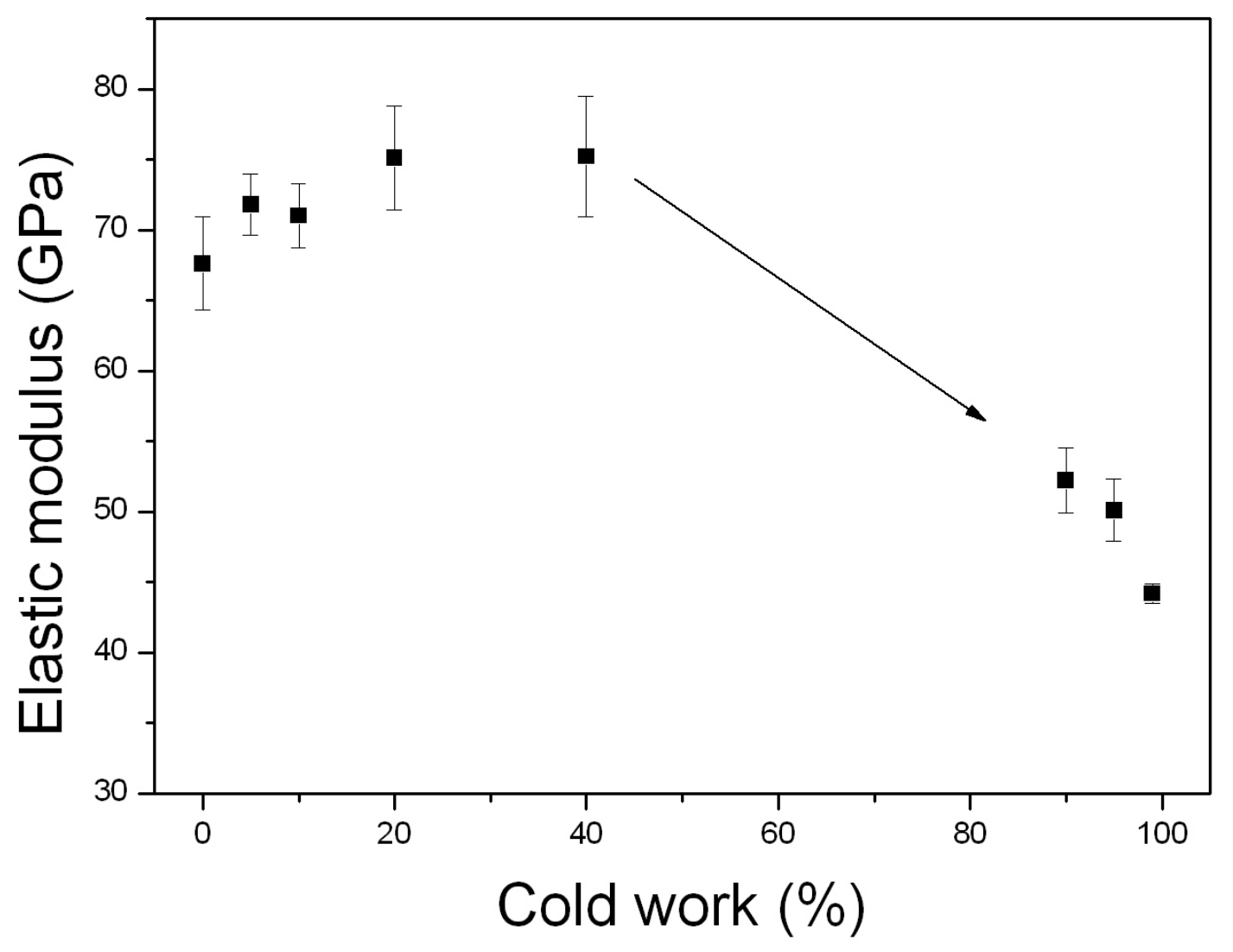

Figure 5. Elastic modulus variation of cold rolled calculated by using a spherical tip. 


\section{Acknowledgements}

With the support of the Generalitat de Catalunya Commission for the Universities and Research of the Department of Innovation, Universities and Companies and the European Social Fund.

\section{References}

1. Niinomi M. Recent research and development in titanium alloys for biomedical applications and healthcare goods. Science and Technology of Advanced Materials, Vol. 4, Issue 5, (2003), pp. 445.

2. Duering T.W., Melton K.N. , Stoeckel D. and Wayman C.M. Engineering aspects of shape memory alloys. Butterworth-Heinemann Ltd., 1990.

3. Hao Y.L. Titanium alloy with extra-low modulus and superelasticity and its producing method and processing thereof. US 2007/0137742 A1 2007.

4. Saito T., Furuta T., Hwang J.H. Multifunctional Alloys Obtained via a Dislocation-Free Plastic Deformation Mechanism. Science 2003; 300:464467.

5. Morinaga M., Yukawa N. Alloy design based on molecular orbital method. Proceedings of the International Conference and Exhibition on Computer Applications to Materials Science and Engineering 1991;803-808.

6. Morinaga, M. Kato, T. Kamimura, M. Fukumoto, I. Harada, K. Kubo. In: Sixth World Conference on Titanium. Francia, vol. 1, 1988, pp. 1601.

7. Fischer-Cripps A.C. Nanoindentation. 2nd ed. Springer, 2004.
8. Yan W., Sun Q., Liu H.Y. Spherical indentation hardness of shape memory alloys. Materials Science and Engineering: A 2006; 425(1-2):278-285.

9. Frick C.P., Lang T.W., Spark K., Gall K. Stressinduced martensitic transformations and shape memory at nanometer scales. Acta Materialia 2006; 54(8):2223-2234.

10. Arciniegas M., Manero J.M., Peña J., Gil F.J., Planell J.A. Study of New Multifunctional Shape Memory and Low Elastic Modulus Ni-Free Ti Alloys. Metallurgical and Materials Transactions A 2008;39(4):742-751.

11. Pharr G.M. Measurement of mechanical properties by ultra-low load indentation. Materials Science and Engineering A 1998; 253(1-2):151-159.

12. Yan W., Sun Q., Feng X.Q., Qian L. Analysis of spherical indentation of superelastic shape memory alloys. International Journal of Solids and Structures 2007; 44(1):1-17.

13. Boyer, R. Materials Properties Handbook: Titanium Alloys. ASM International. 1994; 770

14. Fischer-Cripps A.C. A review of analysis methods for sub-micron indentation testing. Vacuum 2000; 58(4):569-585.

15. Hao Y.L., Li S.J., Sun Y., Zheng C.Y., Hu Q.M., Yang R. Super-elastic titanium alloy with unstable plastic deformation. Applied Physics Letters 2005;87.

16. Hwang J., Kuramoto S., Furuta T., Nishino K., Saito T. Phase-stability dependence of plastic deformation behavior in Ti-Nb-Ta-Zr-O alloys. Journal of Materials Engineering and Performance 2005; 14(6):747-754.

17. Schiøtz J.,Di Tolla F.D., Jacobsen W. Softening of nanocrystalline metals at very small grain sizes. Nature 1998; 391:561-563. 